\title{
Characterization of Interactions between Natural Organic Matter and Metals by Tangential-Flow Ultrafiltration and ICP OES
}

\author{
Adilson C. Santos, ${ }^{a}$ Luciane P. C. Romão, ${ }^{*}, a$ Valéria L. de Oliveira, ${ }^{a}$ Mônica C. Santos, ${ }^{a}$ \\ Carlos A. B. Garcia, ${ }^{a}$ Igor C. Pescara ${ }^{b}$ and Luiz F. Zara ${ }^{c}$
}

\author{
${ }^{a}$ Departmento de Química, Universidade Federal de Sergipe, 49100-000 Aracaju-SE, Brazil \\ ${ }^{b}$ Instituto de Química, Universidade Estadual de Campinas, 13083-970 Campinas-SP, Brazil \\ ${ }^{c}$ Departmento de Controle Ambiental, Universidade de Brasília, Vila Nossa Senhora de Fátima, \\ 73300-000 Planaltina-GO, Brazil
}

\begin{abstract}
O fracionamento por tamanho molecular da matéria orgânica natural (MON) de amostras de água do Parque Nacional Serra de Itabaiana (Brasil) foi utilizado para caracterização temporal da complexação de íons metálicos. Um sistema de ultrafiltração em cinco estágios foi usado para separar a MON em seis frações (F1: > 100; F2: 100-50; F3: 50-30; F4: 30-10; F5: 10-5; F6: < 5 kDa). A distribuição obtida, inicialmente para amostra in natura, mostrou que metais $(\mathrm{Al}, \mathrm{Ba}, \mathrm{Cr}, \mathrm{Cu}, \mathrm{Fe}$, $\mathrm{Mn}, \mathrm{Ni}, \mathrm{Pb}$ e $\mathrm{Sr}$ ) foram complexados, preferencialmente, pela fração $\mathrm{F} 1$, a qual continha maior concentração de carbono orgânico dissolvido (COD). A seguinte ordem decrescente de distribuição de carbono foi obtida: $\mathrm{F} 1>>\mathrm{F} 3>\mathrm{F} 2=\mathrm{F} 4>\mathrm{F} 6>\mathrm{F} 5$. As frações F2 e F5 foram as mais humificadas e F6 a menos humificada. Após 30 dias com adição de elevadas concentrações de metais nas amostras filtradas novas distribuições de COD e metais foram observadas. Maior COD ainda foi encontrado na F1 com teores de carbono decrescendo na seguinte ordem: F1 > F2 > F3 > F4 > F5 > F6. Os metais apresentaram distribuições similares e homogêneas em todas as frações. Valores de log K foram similares para as amostras in natura e para aquelas de 30 dias após a adição dos metais (7,1e 7,0; 6,6 e 6,9; e 7,2 e 7,0 para Al, Cu e Fe-MON, respectivamente), indicando uma nova condição de equilíbrio na distribuição dos metais após 30 dias. As espécies formadas entre MON e os metais adicionados mostraram um modelo de distribuição que mudou em função do tempo de complexação, indicando uma transformação dos sítios de ligação da MON, sugerindo que o efeito coletivo das frações é mais importante que as propriedades individuais e confirmando que as frações mais humificadas exercem grande influência na complexação de metais em ambientes aquáticos.
\end{abstract}

Molecular size fractionation of the natural organic matter (NOM) in water samples from the Serra de Itabaiana National Park (Brazil) was used to characterize the temporal behavior of metal ion complexation. A special five-stage tangential-flow ultrafiltration device was used to separate NOM in six size fractions (F1: > 100; F2: 100-50; F3: 50-30; F4: 30-10; F5: 10-5; F6: < 5 kDa). The distribution patterns obtained for one in natura sample showed that metals $(\mathrm{Al}, \mathrm{Ba}, \mathrm{Cr}, \mathrm{Cu}$, $\mathrm{Fe}, \mathrm{Mn}, \mathrm{Ni}, \mathrm{Pb}$ and $\mathrm{Sr}$ ) were preferentially complexed by the F1 fraction, which contained higher concentration of dissolved organic carbon (DOC). The following decreasing order of carbon distribution in the different fractions was obtained: $\mathrm{F} 1>>\mathrm{F} 3>\mathrm{F} 2=\mathrm{F} 4>\mathrm{F} 6>\mathrm{F} 5$. Fractions $\mathrm{F} 2$ and F5 were the most humified, and F6 the least. New distributions of DOC and metals were observed after 30 days when high concentrations of metals were added to filtered samples. Highest DOC was still found in F1, with carbon contents decreasing in the following order: F1 > F2 > F3 > F4 > F5 > F6. The studied metals presented similar and homogeneous distributions in all fractions. Values of $\log \mathrm{K}$ were similar for samples in natura and 30 days after addition of metals (7.1 and 7.0, 6.6 and 6.9, and 7.2 and 7.0 for $\mathrm{Al}, \mathrm{Cu}$ and $\mathrm{Fe}-\mathrm{NOM}$, respectively), indicating a new dynamic equilibrium in the metals distribution after 30 days. The species formed between NOM and spiked metals showed distribution patterns that changed as a function of complexation time, indicating a transformation of the NOM binding sites, suggesting that the collective effect of the fractions is more important than individual site properties, and confirming that the most humified fractions exert a large influence on the complexation of metals in aquatic environments.

Keywords: metals, natural organic matter, ultrafiltration, conditional equilibrium constants

\footnotetext{
*e-mail: luciane@ufs.br
} 


\section{Introduction}

Various metal species having either natural or anthropic origins are present in the aquatic environment. These metals do not exist in isolation, because natural waters contain a variety of substances, inorganic or organic, capable of forming complexes with dissolved metal ions, and during the complexation process a natural competition occurs between different metals for available binding sites, which can modify the metal balance. ${ }^{1}$ The distribution of metals among various ligands (i.e., metal speciation) also governs bioavailability, which is related to the free metal concentration rather than to the total dissolved metal concentration. This is important, because the deleterious effects of metal toxicity can be mitigated by complexation of the metal with inorganic or organic ligands. Metal speciation may also affect the mobility of metals in aquatic environments, and thus the exposure of organisms to metals. ${ }^{2}$

Organic ligands occur in various forms, including natural organic matter (NOM), a classification that includes all organic substances in a reservoir or natural ecosystem (other than living organisms and compounds of man-made origin). Special attention has been focused on the effects of complexation on processes by which metals are removed from aqueous solutions and which could influence the residence times and concentrations of free dissolved metals, hence directly affecting bioavailability (or biologically available metals) in aquatic environments. Natural OM presents a polyelectrolyte structure, with a large number of polyfunctional groups that are ionized in solution, and different binding sites including carboxylic and phenolic groups, or combinations of these groups. ${ }^{3}$

According to Buffle et al., ${ }^{4}$ complexation sites of natural complexants exert a buffering action over many orders of magnitude of $\log [\mathrm{M}]$, which is essential for maintenance of life in natural systems.

Research concerning the interactions of NOM and metals is therefore vital in order to be able to understand and predict metal binding under different circumstances, and can contribute significantly to knowledge of chemical speciation. ${ }^{1} \mathrm{NOM}$-metal species, and their thermodynamic stability, have been assessed using a variety of techniques. An advantage of the ultrafiltration (UF) method is its ability to combine fractionation, according to molecular mass of the ligand, with sensitive techniques used to determine the total amount of metal in the filtrate (such as atomic absorption or emission spectrometry). ${ }^{5}$

Ultrafiltration systems employing tangential flow (TF) enable relatively rapid filtration, due to reduced pore obstruction since the material accumulated on the membrane surface is removed by the strong cross flow. ${ }^{6}$ According to Burba et al., ${ }^{7}$ UF is one of the few separation methods that do not require either an additional separation medium or additional reagents.

Use of membranes having different cut-offs (5-100 kDa) can provide better information on chemical reactions in freshwater systems involving metals and NOM molecules of different sizes, information about complexation in the environment following inputs of metals, as well as the influence of time on the transformation of NOM-metal compounds formed after varying periods, since time is an important parameter influencing the reactivity of metals with organic matter. Some studies have suggested that recently-complexed metal ions are preferentially linked with easily accessible functional groups in the organic molecules, with reaction time determining structural changes in NOM molecules and variations in the contents of dissolved organic carbon (DOC) and metals in the various molecular size fractions. ${ }^{7-10}$

Information is therefore needed to improve understanding of the dynamics of natural aquatic systems containing elevated DOC contents, and here we use the example of the Serra de Itabaiana National Park watershed (Brazil). This environmentally protected region contains the headwaters of rivers that are important both from the perspective of water supplies for human consumption, and for irrigation projects affecting around 100,000 inhabitants of an arid region of Sergipe State in northeast Brazil.

The distributions of $\mathrm{Al}, \mathrm{Ba}, \mathrm{Cr}, \mathrm{Cu}, \mathrm{Fe}, \mathrm{Mn}, \mathrm{Ni}, \mathrm{Pb}$ and $\mathrm{Sr}$ were characterized in different molecular size fractions, using NOM from water samples obtained from the Serra de Itabaiana, by applying the tangential-flow ultrafiltration (TF-UF) technique. Important information was also obtained concerning thermodynamic properties that dominate metal complexation by natural ligands, with temporally resolved fractionation used to evaluate the influence of this process on the availability and speciation of metals under the experimental conditions of the study.

\section{Experimental}

\section{Sampling and characterization of the in natura sample}

Organic-rich water $(20 \mathrm{~L})$ was collected from the Cachoeira do Cipó stream in the Serra de Itabaiana (Brazil). DOC was determined after filtration through a $0.45 \mu \mathrm{m}$ filter, using catalytic combustion in an oxygen atmosphere (Shimadzu TOC-5000 analyzer). According to Thurman, ${ }^{11}$ DOC is the organic carbon that passes through a $0.45 \mu \mathrm{m}$ pore size filter, and is the most important parameter used in the study of organic carbon. DOC quantifies the chemically 
reactive fraction, and gives the mass of organic carbon dissolved in a water sample. Most of the DOC (both simple and complexed organic molecules) is smaller than the colloidal range of $1 \mathrm{~nm}$ to $0.45 \mu \mathrm{m}$.

The complexation capacity (CC) was determined according to the method proposed by Romão et al.,$^{5}$ for the $\mathrm{Cu}$ (II) ion. Molecular absorption spectrophotometric measurements (Thermo Genesys 10, place) were made in the UV-Vis region at 254 and $436 \mathrm{~nm}$.

\section{Determination of metals}

The metal ions $\left(\mathrm{Al}^{3+}, \mathrm{Ba}^{2+}, \mathrm{Cr}^{3+}, \mathrm{Cu}^{2+}, \mathrm{Fe}^{3+}, \mathrm{Mn}^{2+}\right.$, $\mathrm{Ni}^{2+}, \mathrm{Pb}^{2+}$ and $\mathrm{Sr}^{2+}$ ) were determined using atomic emission spectroscopy in an argon plasma (Varian ICP OES, Mulgrave, Australia), following the instrument manufacturer's recommendations. Acid synthetic standard solutions $\left(0.1 \% \mathrm{v} / \mathrm{v} \mathrm{HNO}_{3}\right)$ were diluted, and working solutions with a final $\mathrm{pH}$ of 2.0 were used for calibration of the ICP OES.

\section{NOM fractionation using TF-UF, and the influence of time}

Different fractions were obtained using a TF-UF system (Vivascience Model Vivaflow 200, place) equipped with polyethersulfone (PES) membrane filters of different sizes $(100,50,30,10$ and $5 \mathrm{kDa})$. After filtration through a $0.45 \mu \mathrm{m}$ membrane, the samples $(1000 \mathrm{~mL})$ were spiked with $\mathrm{Al}^{3+}, \mathrm{Ba}^{2+}, \mathrm{Cr}^{3+}, \mathrm{Cu}^{2+}, \mathrm{Fe}^{3+}, \mathrm{Mn}^{2+}, \mathrm{Ni}^{2+}, \mathrm{Pb}^{2+}$ and $\mathrm{Sr}^{2+}$, in appropriate volumes to obtain final concentrations of 3.0, 20, 7.0, 9.0, 7.0, 7.0, 8.0, 32.0 and $13.0 \mathrm{mg} \mathrm{L}^{-1}$, respectively, and allowed to equilibrate for 1,15 and 30 days. The spiked samples were then pumped through the TF-UF system, and the filtrates, containing metals in six different fractions (F1: > 100; F2: 100-50; F3: 50-30; F4: 30-10; F5: 10-5; F6: <5 kDa) were analyzed by ICP OES. The in natura water sample was also fractionated and analyzed adopting the same procedure, after filtration through a $0.45 \mu \mathrm{m}$ membrane.

The total concentration of added metals should not exceed the complexation capacity (CC). To ensure this, the value of $1.50 \mathrm{mmol} \mathrm{g}^{-1} \mathrm{Cu}$ (II) DOC measured for the water sample studied was used as a reference. This parameter (CC) was chosen because the binding sites of natural complexants serve to maintain complexation buffering, but this capacity is limited. Hence, the values of the concentrations of the nine metal species to be added were determined as $\mathrm{CC} / 9$, giving a value of $0.16 \mathrm{mmol}$ for each metal, which was subsequently converted to absolute mass values (mg). The maximum amount of metal added did not exceed the amount measured (as $\mathrm{mg}$ ) in the in natura sample. The concentration of each added metal was therefore controlled using a value smaller than the difference between $\mathrm{CC}$ and the in natura concentration. The sum of the concentrations of metals could not exceed the $\mathrm{CC}$ of the water, so that their competition and distribution better reflected behavior in the water sample.

\section{Results and Discussion}

A low pH (3.76), and elevated DOC content (22.5 $\left.\mathrm{mg} \mathrm{C} \mathrm{L} \mathrm{L}^{-1}\right)$, as well as the $\mathrm{A}_{254}(0.954)$ and specific absorbance $\left(4.24 \mathrm{~L} \mathrm{mg}^{-1} \mathrm{~m}^{-1}\right)$ values, were all indicative of high humification of the in natura sample. Table 1 shows the DOC composition, and absorbances at 254 and $436 \mathrm{~nm}$ of the NOM fractions. The ratios of the absorbances at 254 and $436 \mathrm{~nm}$ for the different fractions showed that F5 and F2 were the most humified (smaller ratios), with values of 1.47 and 2.42, respectively. Values for the remaining fractions were $9.90(\mathrm{~F} 1), 14.2(\mathrm{~F} 3), 18.2(\mathrm{~F} 4)$ and 27.0 (F6). The following increasing order of humification was obtained: F6 < F4,F3 < F1 < F2 < F5. These results are corroborated by those obtained by Araújo et al., ${ }^{12}$ who also estimated the extent of humification using $\mathrm{A}_{254} / \mathrm{A}_{436}$ ratios. According to Frimmel et al. ${ }^{13}$ absorbance (A) in the UV and visible ranges is an important property of NOM. Moreover, the UV-Visible spectra are featureless and contain no discrete absorption bands, because of the overlap of the broad absorption bands of the chromophores. The spectral absorption also depends on the $\mathrm{pH}$ value. The lower the $\mathrm{pH}$, the lower the specific absorbance, reflecting the acid-base forms of the chromophores within the molecules. Thus, normalization of absorbance on the mass concentration of DOC can be very useful, for both original aqueous samples and isolated fractions. Specific absorbance $\left(\mathrm{A}_{254} / \mathrm{DOC}\right)$ values near or higher than 4.0 are indicative of high humification, and suggestive of an organic matter characterized by a high density of double bonds or the significant presence of aromatic groups. Here, fraction F1 showed the highest DOC percentage, and contained over $50 \%$ of the C of the NOM (Table 1).

Figure 1 shows the initial distributions of DOC and complexed metals in the different fractions. The $\mathrm{F} 1$ fraction contained the greatest amount of DOC, and F5 the least. Carbon contents of the different fractions decreased in the order: F1 $>>$ F3 $>$ F2 $=F 4>F 6>$ F5. There was preferential binding of metals in F1 (the highest DOC fraction).

For all fractions, there was no significant change in the carbon distribution after $24 \mathrm{~h}$ (Figure 2), compared with the initial distribution, and fractionation of spiked samples only showed alterations for some metals. Iron and $\mathrm{Cu}$ showed preferential binding in $\mathrm{F} 1$, which accounted for about 90 and $80 \%$ of the total of these metals, respectively. 
Table 1. Dissolved organic carbon contents, and absorbances at 254 and $436 \mathrm{~nm}$

\begin{tabular}{|c|c|c|c|c|c|c|}
\hline $\begin{array}{l}\text { Fraction } \\
(\mathrm{kDa})\end{array}$ & $\begin{array}{c}\text { DOC } \\
\left(\mathrm{mg} \mathrm{L}^{-1}\right)\end{array}$ & $\begin{array}{c}\text { DOC } \\
(\%, \mathrm{~m} / \mathrm{m})\end{array}$ & $\mathrm{A}_{254}$ & $\mathrm{~A}_{436}$ & $\mathrm{~A}_{254} / \mathrm{A}_{436}$ & $\begin{array}{c}\mathrm{A}_{254} / \mathrm{DOC} \\
\left(\mathrm{L} \mathrm{mg}^{-1} \mathrm{~m}^{-1}\right)\end{array}$ \\
\hline $\mathrm{F} 1(>100)$ & 80.10 & 52.76 & 0.416 & 0.042 & 9.90 & 0.78 \\
\hline F2 (100-50) & 12.81 & 10.97 & 0.588 & 0.243 & 2.42 & 4.59 \\
\hline F3 (50-30) & 8.44 & 12.23 & 0.583 & 0.041 & 14.22 & 1.21 \\
\hline F4 (30-10) & 9.69 & 10.84 & 0.364 & 0.020 & 18.20 & 0.58 \\
\hline F5 (10-5) & 5.57 & 5.14 & 0.210 & 0.142 & 1.47 & 3.77 \\
\hline $\mathrm{F} 6(<5)$ & 5.10 & 8.06 & 0.054 & 0.002 & 27.00 & 0.82 \\
\hline
\end{tabular}

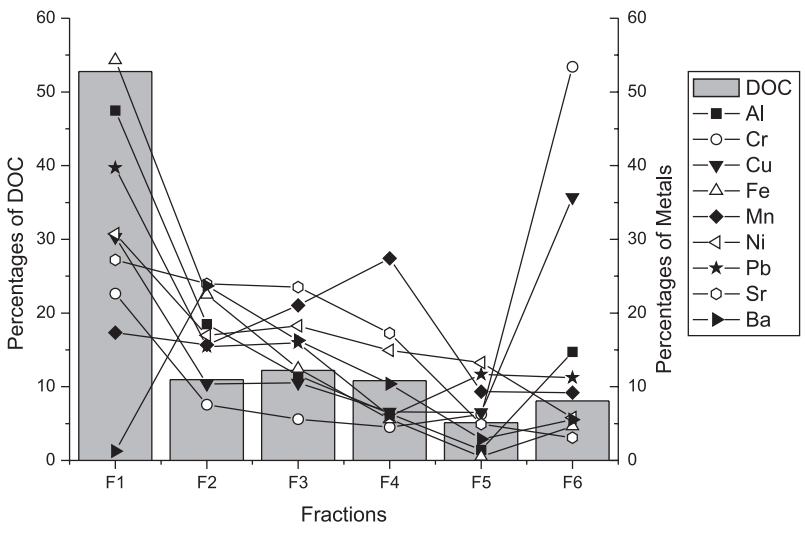

Figure 1. Initial distributions (\%) of DOC and complexed metals in the different NOM size fractions.

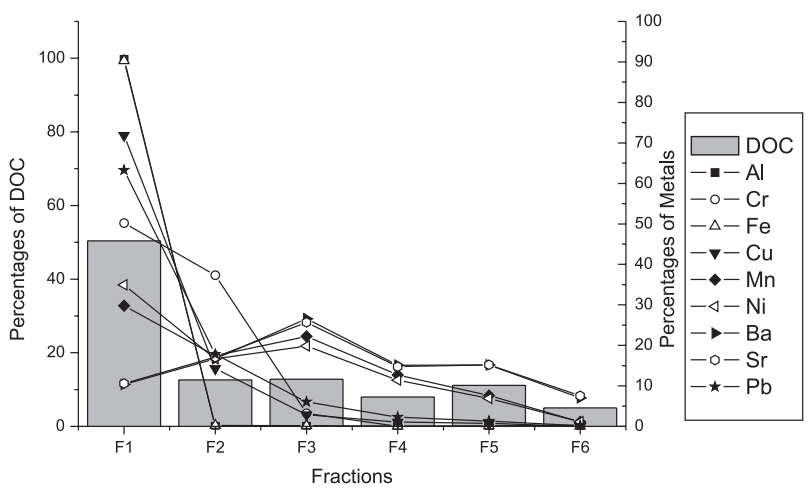

Figure 2. Distributions (\%) of DOC and complexed metals in the different NOM size fractions after 1 day.

Figure 3 presents the distributions after 15 days. F1 shows a decrease of DOC compared with the earlier distributions, but still contains the highest proportion (around 35\%). For the most humified fractions, there was no change in the DOC content of F2 (ca. 12\%), however that of F5 (ca.17\%) increased by more than $300 \%$ compared to the in natura sample, and by $150 \%$ compared to the $24 \mathrm{~h}$ sample. The distribution of the metals was nearly uniform in all fractions.

New distributions of DOC were observed after 30 days (Figure 4). Fraction F1 retained the highest DOC, with carbon contents decreasing in the following order: F1 $>$ F2 $>$ F3 > F4 > F5 > F6. There was a substantial increase $(250 \%)$ in the DOC of $\mathrm{F} 2$, one of the most

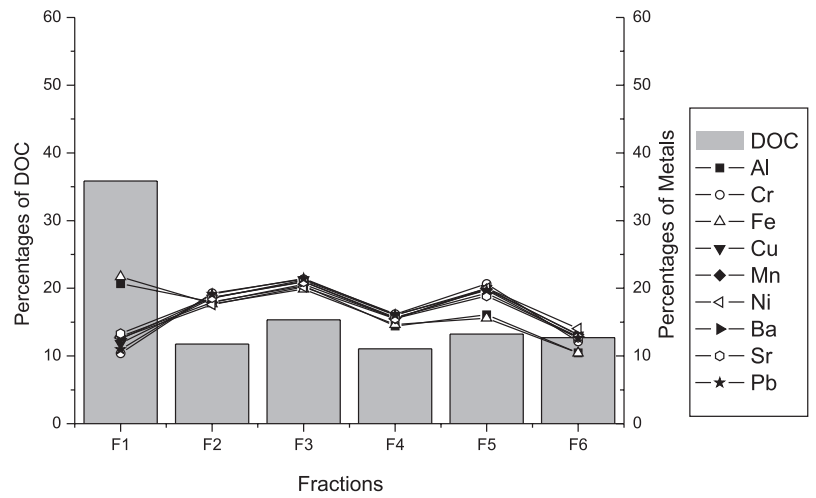

Figure 3. Distributions (\%) of DOC and complexed metals in the different NOM size fractions after 15 days.

humified fractions, relative to the contents of the in natura, $24 \mathrm{~h}$ and 15 day samples. The metals showed similar and homogeneous distributions in all fractions, close to those observed after 15 days, probably indicative of an establishment of equilibrium. These results differ from those obtained by Sargentini et al.,$^{10}$ where a change was observed $24 \mathrm{~h}$ after addition of five metals $(\mathrm{Ni}, \mathrm{Cu}, \mathrm{Zn}, \mathrm{Cd}$ and $\mathrm{Pb}$ ), with a return to a distribution similar to that of the in natura sample after 10 days. Conditions were not identical, with the earlier study being of shorter duration, the NOM (denoted aquatic humic substances) extracted using XAD-8 resin, and the water sample obtained from the Rio Negro in the northern Amazon basin (Brazil). Nonetheless, there are similarities in the findings of both studies, with evidence for the occurrence of intra/interrearrangements of NOM binding sites, and a homogeneous trend of metal distributions in all size fractions. ${ }^{9}$

In order to explore the possible degradation of NOM, the water sample was placed under agitation for 30 days, after which ultrafiltration was performed and the carbon content measured after 1, 15 and 30 days. Table 2 shows the variation of the percentage of carbon, as a function of time, with t0 representing the in natura sample. The values obtained show that spontaneous degradation of the organic matter did not occur, and that the variations in DOC percentages observed in the binding time experiments were a result of NOM intra/inter-rearrangements. 


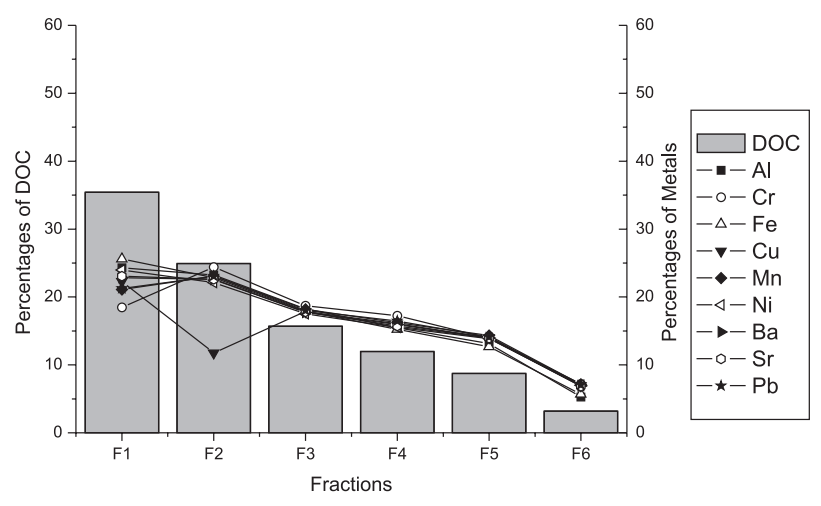

Figure 4. Distributions (\%) of DOC and complexed metals in the different NOM size fractions after 30 days.

Table 2. Dissolved organic carbon contents (\%) in different fractions as a function of complexation time ( $0,1,15$ and 30 days)

\begin{tabular}{lcccc}
\hline Fraction & $\mathrm{t} 0$ & $\mathrm{t} 1$ & $\mathrm{t} 15$ & $\mathrm{t} 30$ \\
\hline F1 & 52.8 & 53.1 & 52.9 & 52.6 \\
F2 & 10.8 & 10.1 & 11.1 & 10.5 \\
F3 & 12.2 & 12.0 & 12.4 & 12.1 \\
F4 & 10.8 & 11.0 & 10.9 & 10.9 \\
F5 & 5.14 & 6.15 & 6.00 & 5.30 \\
F6 & 8.06 & 7.69 & 6.74 & 8.60 \\
\hline
\end{tabular}

Table 3 shows the values of the conditional stability constants (K) of the metal-NOM complexes (where the metal is $\mathrm{Al}, \mathrm{Cu}$ or $\mathrm{Fe}$ ), determined considering the first five fractions at times 0 (in natura sample) and 30 days after addition of the metals. The $\mathrm{pH}$ was maintained constant at 5.0. The model used for the calculation was as suggested by Nifant'eva et al.,${ }^{14}$ where the complexation reaction is described as follows:

$M+L_{i} M L_{i}$

$K_{i}=\frac{\left[M-L_{i}\right]}{[M]\left[L_{i}\right]}$

$K=\sum K_{i} \alpha_{i}$

$a_{i}=\frac{\left[L_{i}\right]}{\sum\left[L_{i}\right]}$

$\left[\mathrm{M}-\mathrm{L}_{\mathrm{i}}\right]=$ concentration of complex retained on stage $\mathrm{i}$ of the UF system. This is achieved by determining the metal concentration in each return; $[\mathrm{M}]=$ concentration of free metal, which passed through all five UF stages. This corresponds to the concentration of metal in fraction F6; $\left[\mathrm{L}_{\mathrm{i}}\right]=$ concentration of ligand calculated from $50 \%$ of the DOC for each UF stage.

The results (Table 3) show that, for all metals, the highest $\mathrm{K}$ values were obtained for the highest molecular weight fractions. Similar results were obtained by
Nifant'eva et al. ${ }^{14}$ Conditional stability constant values for $\mathrm{Cu}-\mathrm{HS}$, obtained using different analytical methods can be found in the literature. ${ }^{5}$ The equilibrium quotients are constants, and comparable only if measured at constant $\mathrm{pH}$. At $\mathrm{pH} 5.0$, the main groups $(-\mathrm{COOH})$ are ionized and to enable comparison with other work it was necessary to select a specific $\mathrm{pH}$ value. According to Tipping, ${ }^{2}$ the binding of metal cations is strongly affected by $\mathrm{pH}$, firstly due to the competition between protons and metal cations for organic matter binding sites (low $\mathrm{pH}$ ), and secondly because of cation hydrolysis (high $\mathrm{pH}$ ). At $\mathrm{pH}$ values higher than 6.0, the species $\left[\mathrm{Al}(\mathrm{OH})_{2}\right]^{+}$and $\left[\mathrm{Al}(\mathrm{OH})_{4}\right]^{-}$are assumed not to bind, while $\mathrm{Cr}$ (III) tends to precipitate (as $\left.\mathrm{Cr}(\mathrm{OH})_{3}\right)$ under the same conditions. ${ }^{15}$

According to Nifant'eva et al.,$^{14}$ at $\mathrm{pH} 5.0$ and 6.0, $\log \mathrm{K}$ values for $\mathrm{Zn}^{2+}$ and $\mathrm{Cu}^{2+}$ are in the range 4.5-5.4, in agreement with conditional stability constants determined using different analytical techniques. The values are close to those obtained in the present work.

Table 3. Conditional stability constants of $\mathrm{Al}, \mathrm{Cu}$ and $\mathrm{Fe}$ complexes with different NOM fractions, and overall stability constant for samples in natura and 30 days after spiking with metals

\begin{tabular}{|c|c|c|c|c|c|}
\hline \multirow{2}{*}{ Metal } & \multirow{2}{*}{ Fraction } & \multicolumn{2}{|c|}{ in natura } & \multicolumn{2}{|c|}{ After 30 days } \\
\hline & & $\log \mathrm{K}_{\mathrm{i}}$ & $\log \mathrm{K}$ & $\log \mathrm{K}_{\mathrm{i}}$ & $\log K$ \\
\hline \multirow[t]{5}{*}{$\mathrm{Al}$} & $\mathrm{F} 1$ & 7.5 & & 7.7 & \\
\hline & $\mathrm{F} 2$ & 7.5 & & 7.4 & \\
\hline & $\mathrm{F} 3$ & 7.2 & 7.1 & 7.2 & 7.0 \\
\hline & $\mathrm{F} 4$ & 6.6 & & 6.7 & \\
\hline & F5 & 4.6 & & 6.6 & \\
\hline \multirow[t]{5}{*}{$\mathrm{Cu}$} & $\mathrm{F} 1$ & 6.9 & & 7.5 & \\
\hline & $\mathrm{F} 2$ & 6.8 & & 7.3 & \\
\hline & F3 & 6.7 & 6.6 & 7.1 & 6.9 \\
\hline & $\mathrm{F} 4$ & 6.2 & & 6.6 & \\
\hline & F5 & 5.9 & & 6.5 & \\
\hline \multirow[t]{5}{*}{$\mathrm{Fe}$} & $\mathrm{F} 1$ & 7.6 & & 7.7 & \\
\hline & $\mathrm{F} 2$ & 7.5 & & 7.4 & \\
\hline & F3 & 7.2 & 7.2 & 7.2 & 7.0 \\
\hline & $\mathrm{F} 4$ & 7.0 & & 6.6 & \\
\hline & F5 & 5.7 & & 6.6 & \\
\hline
\end{tabular}

For the in natura sample and that obtained 30 days after metal addition, the $\log \mathrm{K}$ values are similar for $\mathrm{Al}$, $\mathrm{Cu}$ and $\mathrm{Fe}-\mathrm{NOM}$ (7.1 and 7.0, 6.6 and 6.9, and 7.2 and 7.0 , respectively), confirming that equilibrium was attained in the metal distribution after 30 days. It is important to emphasize the contribution of the most humified fractions, especially $\mathrm{F} 5$ where $\log \mathrm{K}_{\mathrm{i}}$ increased from 4.6 to 6.6 for $\mathrm{Al}$, from 5.9 to 6.5 for $\mathrm{Cu}$, and from 5.7 to 6.6 for $\mathrm{Fe}$. These increments significantly influenced the final value of $\log \mathrm{K}$. According to Buffle et al. ${ }^{4}$ the buffering behavior of natural heterogeneous complexants plays an important role 
in controlling free metal ion concentrations. This suggests that the overall effect of organic fractions of differing molecular size is more important than individual site properties, and indicates that the most humified fractions exert a large influence on the complexation of metals in the aquatic environment, and therefore on transport processes, accumulation and bioavailability of metals in natural waters.

\section{Conclusions}

Under the conditions employed in this work, use of a five-stage tangential-flow ultrafiltration device showed that the distribution patterns of metals and NOM fractions changed as a function of kinetics (time) and thermodynamic properties. There was strong evidence for the participation of humified fractions in controlling metal concentrations, as well as the distribution and speciation of metals in aquatic environments.

\section{Acknowledgements}

The financial support of this work by CAPES and FAPITEC/SE is gratefully acknowledged.

\section{References}

1. Buffle J.; Complexation Reactions in Aquatic Systems: An Analytical Approach, J. Wiley and Sons: New York, 1990.

2. Tipping E; Cation Binding by Humic Substances, Cambridge University Press: New York, 2002.
3. Lund, W.; Metal Speciation in the Environment; SpringerVerlag: Berlin, 1990.

4. Buffle, J.; Altmann, R. S.; Filella, M.; Anal. Chim. Acta 1990, 232, 225.

5. Romão, L. P. C.; Castro, G. R.; Rosa, A. H.; Rocha, J. C.; Padilha, P. M.; Silva, H. C.; Anal. Bioanal. Chem. 2003, 375, 1097.

6. Rocha, J. C.; Sargentini Jr., E.; Zara, L. F.; Rosa, A. H.; Santos, A.; Burba, P.; Talanta 2000, 53, 551.

7. Burba, P.; Aster, B.; Nifant'eva, T.; Shkinev, V.; Spivakov, B. Y.; Talanta 1998, 45, 977.

8. Burba, P.; Fresenius J. Anal. Chem. 1994, 348, 301.

9. Sargentini Jr., E.; Rocha, J. C.; Rosa, A. H.; Zara, L. F.; Santos, A.; Quim. Nova 2001, 24, 339.

10. Lippold, H.; Evans, N. D. M.; Warwick, P.; Kupsch, H.; Chemosphere 2007, 67, 1050.

11. Thurman, E. M.; Organic Geochemistry of Natural Waters; Kluwer Academic; Boston, 1985.

12. Araújo, A. B.; Rosa, A. H.; Rocha, J. C.; Romão, L. P. C.; Quim. Nova 2002, 25, 1103.

13. Frimmel, F. H.; Abbt-Braun, G.; Heumann, K. G.; Hock, B.; Ludemann, H. D.; Spiteller, M.; Refractory Organic Substances in the Environment, Wiley-VCH: Weinheim, 2002.

14. Nifant'eva, T. I.; Burba, P.; Fedorova, O.; Shkinev, V. M.; Spivakov, B. Y.; Talanta 2001, 53, 1127.

15. Mohan, D.; Pittman Jr., C. U.; J. Hazard. Mater. 2006, 137, 762.

Submitted: January 20, 2010

Published online: August 12, 2010

FAPESP has sponsored the publication of this article. 